\title{
Various Aspects of The Implementation of SIMDA Which Influence The Quality of Financial Statement with The Role of PPK-SKPD as Moderating Variable (A Case Study at The SKPD of Deli Serdang Regency)
}

\author{
Agustina \\ Accountancy Department \\ Universitas Sumatera Utara \\ Medan, Indonesia \\ atina4224@gmail.com
}

Tapi Anda Sari Lubis

Accountancy Department

Universitas Sumatera Utara

Medan, Indonesia

\author{
Iskandar Muda \\ Accountancy Department \\ Universitas Sumatera Utara \\ Medan, Indonesia
}

\begin{abstract}
The objective of this study was to examine some factors which influence the financial statement quality of SKPD (Regional Work Unit) of the Deli Serdang District Government with the role of PPK-SKPD as moderating variable. The study used causal comparative method with primary data. The population was 101, and the data were gathered by directly using questionnaires. The hypothesis was tested by using multivariate analysis with SEM software program, and the moderating variable was tested by using residual test. The result of the study showed that, partially, the knowledge of using technological information, reconciliation, and internal control system had positive and significant influence on the quality of financial statement, while the capacity of human resources had positive and insignificant influence. PPK-SKPD as moderating variable could not moderate the correlation the use of technological information, capacity of human resources, reconciliation, and internal control system with the quality of the financial statement.
\end{abstract}

Keywords: Use of Technological Information; Capacity of Human Resources; Reconciliation; Internal Control System; Quality of Financial Statement; Role of PPK-SKPD

\section{INTRODUCTION}

The Government is a reporting entity that must make financial statements as a form of liability because (a) the government controls and controls significant resources; (b) the use of such resources by the government may have a profound impact on the welfare and the economy of the people; and (c) there is a separation between management and ownership of these sources[1].

The form of accountability report on local financial management during one budget year is in the form of Local Government Financial Report (LKPD), which consists of Budget Realization Report, Balance Sheet, Cash Flow Report, and Notes to Financial Statement. LKPD must follow Government Accounting Standards[2].
LKPD must meet the criteria of qualitative characteristics of government financial statements as required by Government Regulation Number 24 Year 2005 which are: (1) relevant, (2) reliable, (3) comparable, and (4) understandable, meaning local government is able to realize transparency and accountability in local financial management.

The problems that occurred during the last five years in Deli Serdang District from 2011-2015 in each presentation of LKPD are still some findings about non-compliance with laws and regulations and the weakness of the Government Internal Control System (SPIP) which are both criteria of the assessment of information finance presented so as to affect the opinion and quality of the LKPD. The opinion of BPK-RI on LKPD of Deli Serdang Regency based on Report of Examination Result (LHP) on LKPD that in 2015 get opinion of Not Provide Opinion (TMP) [3].

The phenomenon of local government financial reporting is something interesting to be studied further. The reality in the government financial report is still presented a lot of data that are not appropriate and there are still many deviations found successfully by BPK-RI in the audit of government financial statements. The problems that are often found are related to the preparation and presentation of realization of revenues in regional treasury, fixed assets, local taxes receivables, accumulated depreciation, other short-term debt, as well as realization of local tax revenues and grant revenues. Then BPK asks for reconciliation done per day, while what is done so far is per month[4].

Based on PP no. 65 Year 2010 on Regional Financial Information System, local governments are obliged to develop and utilize information technology progress to improve the ability to manage local finances and distribute regional financial information to the public[5]. One form of utilization of information technology is the use of software as a tool in the accounting system and local finance. Therefore, a good financial management system is required to manage 
.............es accurately, on time, transparently and accountably.

An action plan to improve the quality of the 2014 financial statements, the Deli Serdang District Government has undertaken various follow-up actions as recommended by BPK in its audit reports. These efforts, among others, ordered all SKPD to arrange the procurement of assets in 2014 and previous years which according to the CPC has not been in accordance with government accounting standards and have not believed its reasonableness. In other efforts, from 2014 BPK has cooperated with BPKP Representative of North Sumatera Province[6], especially Deli Serdang Regency to make improvements from the management of regional income and regional financial information through the implementation of local financial system or SIMDA.

PP No. 65 of 2010 to utilize information technology through the implementation of SIMDA[5], some cities and regencies in North Sumatra have slowly implemented SIMDA, one of them is the Government of Deli Serdang Regency which has successfully implemented SIMDA Finance as a whole. The purpose of this SIMDA Finance is to produce financial reports and financial information in a timely, complete, accurate and reliable manner in accordance with the stipulated provisions and encourage the realization of good governance in general and the implementation of local financial management by providing regional technology-based financial management system information in particular.

BPK's assessment of the financial report of Deli Serdang Regency until 2013 is still TMP, in 2014 Deli Serdang Regency has received WDP assessment and in 2015 Deli Serdang regency get TMP again[3]. The cause of the acquisition of these opinions, dominated by the assessment of assets that are not believed to be fairness of a very large amount. Here is the opinion of LKPD Kabupaten Deli Serdang in the last five years.

Table 1.1

List of Opinions LKPD Kabupaten Deli Serdang

\begin{tabular}{ccc}
\hline & Year & Opinion \\
\hline 2011 & TMP \\
\hline 2012 & TW \\
\hline 2013 & TMP \\
\hline 2014 & WDP \\
\hline Source: IHPS I Year 2016 &
\end{tabular}

Based on the above description, this study will examine the relationship between the use of information technology, human resource capacity, reconciliation and internal control system by taking the title "Various Aspects of Application of SIMDA Affecting the Quality of Financial Statements with the Role of PPK-SKPD as Moderating Variables SKPD Deli Serdang)".

\section{A. Formulation of the Problem}

Based on the above, then the formulation of the problem in this study are as follows:
1. Is the use of information technology, human resource capacity, reconciliation and internal control system partially affected the quality of financial statements?

2. Is the role of KDP-SKPD able to moderate the relationship between the use of information technology, human resource capacity, reconciliation and internal control system with the quality of financial statements?

\section{B. Research Purposes}

The purpose of this study is to get an idea of:

1. To analyze the utilization of information technology, human resource capacity, reconciliation and internal control system partially to the quality of financial statements.

2. To analyze the correlation between moderation variable that is role of PPK-SKPD with variable utilization of information technology, human resource capacity, reconciliation and internal control system with quality of financial report.

\section{Benefits of Research}

1. For Researchers. The results of this study may be useful for researchers in particular and become a reference for the next researchers, in increasing knowledge and provide confidence about the use of information technology, human resources capacity, reconciliation and internal control system to the quality of financial statements.

2. For Academics. The results of this study are expected to be useful for academics as a reference to increasing the knowledge of academics regarding the utilization of information technology, human resources capacity, reconciliation and internal control system to the quality of financial statements.

3. Regional Government of Deli Serdang Regency. The results of this study are expected to be a consideration in the implementation of SIMDA on the supporting factors in its implementation in the field and the steps to realize or achieve these factors as well as the quality of information resulting from its application.

\section{THE LITERATURE AND DEVELOPMENT OF HYPOTHESES}

\section{A. Quality of Local Government Financial Statements}

According to Government Regulation no. 71 Year 2010 on Accrual Based Government Accounting Standards states that government financial reporting has the following objectives[2]:

1. Provide information on the source, allocation, and use of financial resources.

2. Provide information on the adequacy of period receipts to finance all expenditures.

3. Provide information on the amount of economic resources used in the activities of reporting entities and the results achieved.

4. Provides information on how the reporting entity is funding all its activities in meeting its cash needs.

5. Provide information on the financial position and condition of the reporting entity in relation to sources of receipt, both short-term and long-term, including those from taxes and lending.

6. Provide information on changes in the financial position of the reporting entity, whether increased or decreased, as a result of activities carried out during the reporting period. 
... ou...nment organizations, the general objectives of accounting and financial statements[7] are:

1. To provide information used in economic, social, and political decision-making as well as various accountability and stewardships.

2. To provide information used to evaluate material and organizational performance.

Characteristics of Financial Statements according to Government Regulation No.71 Year 2010 states[2] "Qualitative characteristics of financial statements are normative measures that need to be realized in accounting information so as to meet its objectives". The following four characteristics are the normative prerequisites required for government financial reports to meet the desired quality: relevant, reliable, comparable and understandable.

Government Regulation No.71 of 2010 states that the components of the local government financial statements include: Budget Realization Report (LRA), Report of Changes in the Over Budget (SAL Change Report), balance sheet, Operational Report, Cash Flow Report, Statement of Changes in Equity, Notes to Report Finance. The Local Government Financial Report (LKPD) is the last phase of the local government accounting process. The public sector financial report is essentially a form of government accountability to the people for the management of public funds either from taxes, user charges or other transactions.

Statement of Government Accounting Standards (PSAP) Number 1 paragraph 9 as contained in Government Regulation Number 71 of 2010 [2] states that financial statements are structured reports on the financial position and transactions conducted by a reporting entity. The general purpose of the financial statements is to provide information on the financial position, budget realization, cash flow, and financial performance of a reporting entity that is useful to users in creating and evaluating decisions on resource allocation. Basically, the government's financial report is the assertion of the government management that provides useful information for decision-making and to show the reporting entity's accountability of the resources entrusted to it.

The financial statements are primarily used to compare the realization of revenues, expenditures, transfers, and financing with the prescribed budget, assess the financial condition, evaluate the effectiveness and efficiency of a reporting entity, and help determine its compliance with laws and regulations. In general, the objectives and functions of the public sector financial report are: 1) Compliance and stewardship; 2) Accountability and retrospective reporting; 3 ) Planning and authorization information; 4) Viability; 5) Public relations; and 6) Source of facts and figures. The financial statements play an important role to fulfill the government's obligations to its public in a democratic society[8].

\section{B. Utilization of Information Technology}

The obligation to utilize information technology by the Government and Regional Government shall be regulated in Government Regulation Number 65 Year 2010 regarding Regional Financial Information System. With the information technology is expected to assist in the process of financial reporting so as to produce reliable and timely financial reports.
The benefits of the application of information technology systems that can provide consistent data processing compared to the manual system because there is diversity of transaction processing with the same control system and accounting reporting using the computer can improve the effectiveness of company management in analyzing, supervising, and review the company's operational activities[9].

Application of regional management information system is an integrated computer application program and can assist the administrative process of local government from provincial, district/city, to sub-district and urban village level. SIMDA consists of 26 separate applications that can be distributed in each SKPD with an integrated database system, so that the output can be used by local leaders to assist the decision-making process. On the other hand, the legislature can use it to monitor the performance of local government. SIMDA is one of the efforts in order to meet the information needs quickly, accurately, completely, accurately, and integrated, to support the process of government administration, public service, and facilitate public participation and dialogue in policy formulation.

The purpose of application of SIMDA[6] is:

a. As a place to exchange information for each SIMDA network connectivity unit connectivity;

b. As a direct communication tool using a webcam for the SIMDA network connectivity work unit;

c. As one of the controlled media for the realization of activities, both physical achievements and the absorption of funds;

d. As the initial media for the implementation of egovernance; and

e. As a means to implement good governance.

Benefits gained by local governments using SIMDA integrated regional finance system (BPKP, 2008) are as follows:

a. Integrated database, do not need repetitive input of the same data;

b. The same data will be checked and re-checked automatically (data validation is assured); and

c. Flexible, can produce information according to the needs where:

d. Output can be adjusted according to applicable legislation, and Output can be presented based on the needs of local government management to make decisions/policies.

\section{Human Resource Capacity}

The capacity of human resources is the ability of a person or an individual, an organization (institutional), or a system to carry out its functions or authorities to achieve its objectives effectively and efficiently. Capacity must be seen as the ability to achieve performance, to produce outputs and outcomes.

\section{Reconciliation}

Reconciliation is a process of matching financial transaction data that is processed with several different systems/subsystems based on the same source document. That reconciliation is one of the keys in the preparation of credible financial statements[10]. This is due to its important role in order to minimize the occurrence of recording differences that impact on the validity and accuracy of the data presented in the financial statements. 
.... ..... lementation of reconciliation must have a purpose that is to minimize the occurrence of recording differences that impact on the validity and accuracy of data presented in the financial statements. In case of any data discrepancies, reconciliation can detect and determine the cause of the difference. In order for reliable accounting data to be generated, it is necessary to perform reconciliation procedures for the accuracy and accuracy of recording of accounting data. With the reconciliation of both the internal SKPD and reconciliation between SKPD with the Finance Bureau, it can produce accurate data that also helped improve the quality of financial statements.

\section{E. Government Internal Control System}

The interaction between people and systems and system implementation is an important factor that affects the quality of information[11]. The reliability of the system must also be supported by the reliability of human resources. But the system that has been running must be controlled in order to keep it running well.

According to Government Regulation of the Republic of Indonesia No. 60 Year 2008 The Government Internal Control System is an integral process of actions and activities undertaken continuously by the leadership and all employees to provide reasonable assurance on the achievement of organizational goals through effective and efficient activities, reliability of financial reporting, security of state assets, and compliance against the legislation[12]. The Government Internal Control System (SPIP) is an internal control system that is run throughout the central government and local government.

SPIP is a concrete step of the government in providing guidance and a foothold for local governments in order that financial management can be implemented accountably and transparently. Sub-components of control activities related to financial reporting are (1) adequate design and use of numbered documents and records; (2) segregation of duties; (3) adequate authorization of transactions; (4) independent examination of performance; and (5) appropriate assessment of the amounts recorded[13].

\section{F. The Role of SKPD Finance Administration Officer}

The role of PPK-SKPD consists of verification process, issuing MSS, performing SKPD accounting functions and preparing financial statements. If the PPK-SKPD performs its duties optimally it will also produce good SKPD Financial Statements, it is because the PPP-SKPD plays an important role starting from examining the completeness of the disbursement, verifying the evidence of expenditure to preparing the Budget Realization Report (LRA), Balance
Sheet and Notes to the Financial Statements (CaLK) in a SKPD Financial Statement.

A financial administration official-SKPD needs to understand the task as a function of financial administration in SKPD well. This section is the function of verification and simultaneously accounting SKPD done. Two important outputs of this section are the documents of the Pay Order (SPM) and the SKPD Financial Statement which are important documents in the management of local finances. Therefore, it is necessary an understanding of accounting that must be owned by a PPK-SKPD. Because it will be easier to translate every transaction that occurs.

Examine the quality of Local Government Financial Statements: Influencing Factors and Policy Implications (Study on SKPD of Central Java Provincial Government)[10]. This research is an explanatory research of 48 SKPD in Central Java Provincial Government, using questionnaires in data collection. The quality of SKPD's financial report in the scope of Central Java Provincial Government has not reached the good category. The majority $(66.67 \%)$ of SKPD's financial statements are in sufficient and insufficient category, in particular reports on the summary of financial performance achievement, explanation of financial report items, detailed explanation of property and quipment. The main factor causing the poor quality of SKPD financial report in Central Java Provincial Government is not yet optimal implementation of internal control system, even many SKPD still do not have technical guidance. The second factor is the lack of qualified financial personnel in the field of finance, this is evident from the level of understanding of staff/staff about basic knowledge of financial/accounting is not adequate. The third factor is the lack of means associated with financial information technology.

\section{G. Conceptual Framework}

In summary, the conceptual framework that explains the factors that influence the suitability of the implementation of SIMDA with the role of PPK-SKPD as a moderator variable can be seen as follows:

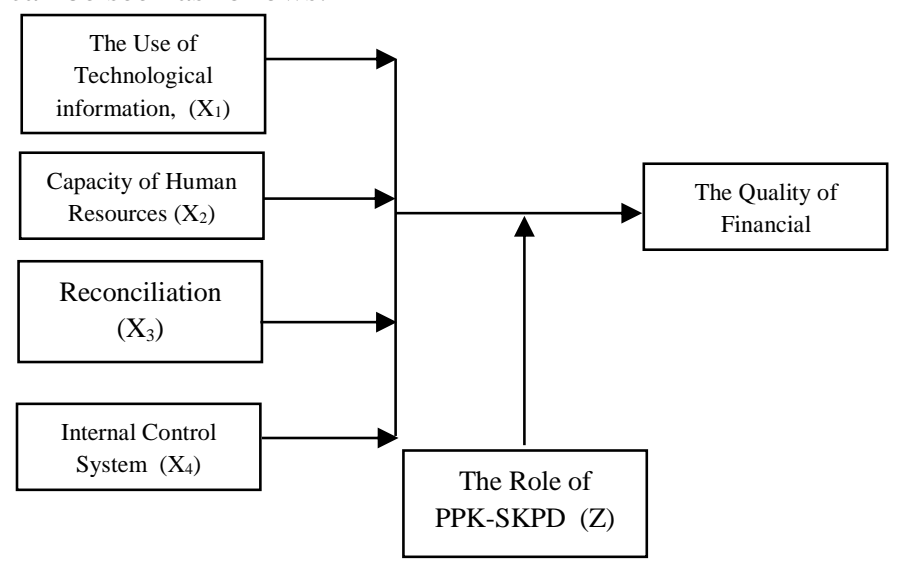

Figure 2.1 Concept Framework

The hypothesis of this research is as follows:

1. Utilization of information technology, human resource capacity, reconciliation and internal control system partially influence the quality of local government financial reports on SKPD in Deli Serdang Regency.

2. The role of PPK-SKPD is able to moderate the relationship between the use of information technology, human resource capacity, reconciliation and internal 
ystem with the quality of local government

financial reports on SKPD in Deli Serdang Regency.

\section{RESEARCH METHODS}

The method of collecting primary data in this research is using questionnaire instrument filled by Head of
Finance Sub-division, Expenditure Treasurer, Acceptance Treasurer and SIMDA Operator at 31 SKPD of Deli Serdang Regency Government. Total respondents who become members of the population and will be given questionnaires as many as 101 respondents

Table 3.1 Operational Definition

\begin{tabular}{|c|c|c|c|}
\hline Variables & Operational definition & Indicator & Scale \\
\hline $\begin{array}{l}\text { Quality of } \\
\text { Financial } \\
\text { Statements (Y) }\end{array}$ & $\begin{array}{l}\text { Normative measures that need } \\
\text { to be manifested in accounting } \\
\text { information so as to meet its } \\
\text { objectives }\end{array}$ & $\begin{array}{ll}\text { - } & \text { Relevant } \\
\text { - } & \text { Reliable } \\
\text { - } & \text { Can be compared } \\
\text { - } & \text { Understandable } \\
\end{array}$ & Interval \\
\hline $\begin{array}{l}\text { Utilization of } \\
\text { Information } \\
\text { Technology } \\
\text { (X1) }\end{array}$ & $\begin{array}{l}\text { Development and utilization of } \\
\text { information technology } \\
\text { progress to improve financial } \\
\text { management capability, and } \\
\text { channel financial information to } \\
\text { public service }\end{array}$ & $\begin{array}{ll} & \text { Computer } \\
\text { - } & \text { Internet Network }\end{array}$ & Interval \\
\hline $\begin{array}{l}\text { Human } \\
\text { Resource } \\
\text { Capacity } \\
\left(\mathrm{X}_{2}\right)\end{array}$ & $\begin{array}{l}\text { Ability either in the individual, } \\
\text { organizational/institutional, or } \\
\text { system level to perform its } \\
\text { functions or authorities to } \\
\text { achieve its objectives } \\
\text { effectively and efficiently }\end{array}$ & $\begin{array}{ll}\text { - } & \text { Responsible } \\
\text { - } & \text { Training } \\
\text { - } & \text { Experience }\end{array}$ & Interval \\
\hline $\begin{array}{l}\text { Reconciliation } \\
\left(\mathrm{X}_{3}\right)\end{array}$ & $\begin{array}{l}\text { Reconciliation is the matching } \\
\text { of data on Regional } \\
\text { Assets/assets with the balance } \\
\text { sheet }\end{array}$ & $\begin{array}{ll}\text { - } & \text { Compatibility } \\
\text { - } & \text { Reliability }\end{array}$ & Interval \\
\hline $\begin{array}{l}\text { Internal Control } \\
\text { System } \\
\left(\mathrm{X}_{4}\right)\end{array}$ & $\begin{array}{l}\text { An integral process of actions } \\
\text { and activities perpetuated by } \\
\text { the leadership and all } \\
\text { employees to provide } \\
\text { reasonable assurance on the } \\
\text { achievement of organizational } \\
\text { goals }\end{array}$ & $\begin{array}{ll}\text { - } & \text { Control environment } \\
\text { - } & \text { Risk assessment } \\
\text { - } & \text { Control activities } \\
\text { - } & \text { Information and } \\
\text { - } & \text { communication } \\
\text { Monitoring }\end{array}$ & Interval \\
\hline $\begin{array}{l}\text { The role of } \\
\text { PPK-SKPD } \\
(\mathrm{Z})\end{array}$ & $\begin{array}{l}\text { Officials performing the } \\
\text { administrative functions of } \\
\text { finance in SKPD }\end{array}$ & $\begin{array}{ll}- & \text { Educational } \\
\text { background } \\
\text { - } \\
\text { Ongoing education and } \\
\text { training } \\
\text { - } \\
\text { PPK performance }\end{array}$ & Interval \\
\hline
\end{tabular}

\section{A. Data Analysis Method}

Data analysis method used in this research is quantitative analysis by using SEM model (Structural Equation Modeling) or Structural Equation Model with AMOS program[14]. 


\section{IV.RESULTS AND DISCUSSION}

Table 4.1 Respondents Answer Description

Descriptive Statistics

\begin{tabular}{lccccc}
\hline & $\mathrm{N}$ & Minimum & Maximum & Mean & Std. Deviation \\
\hline $\begin{array}{l}\text { Quality of Financial Statements } \\
\text { (Y) }\end{array}$ & 61 & 2.00 & 5.00 & 4.1282 & .43799 \\
$\begin{array}{l}\text { Utilization of Information } \\
\text { Technology (X1) }\end{array}$ & 61 & 2.71 & 5.00 & 4.3817 & .49330 \\
\hline $\begin{array}{l}\text { Human Resource Capacity } \\
(\mathrm{X} 2)\end{array}$ & 61 & 2.00 & 5.00 & 4.3279 & .47826 \\
\hline Reconciliation (X3) & 61 & 2.00 & 5.00 & 3.6967 & .42295 \\
\hline Internal Control System(X4) & 61 & 2.00 & 5.00 & 4.1355 & .43444 \\
\hline The role of PPK-SKPD(Z) & 61 & 3.65 & 5.00 & 4.1996 & .34187 \\
\hline Valid N (listwise) & 61 & & & & \\
\hline
\end{tabular}

Source: Data processed 2017

\section{A. Research}

1) Classic Assumption Test

The classical assumption test used in this research includes normality test and multicollinearity test.

\section{2) Normality Test}

Table 4.2 Normality Test with AMOS

Assessment of normality (Group number l)
\begin{tabular}{|l|rrrrrr|}
\hline Variable & $\min$ & $\max$ & skew & c.r. & kurtosis & c.r. \\
\hline X4 & 30.000 & 75.000 & -2.205 & -7.030 & 8.512 & 13.570 \\
X3 & 16.000 & 40.000 & -.544 & -1.736 & 3.831 & 6.108 \\
X2 & 16.000 & 40.000 & -1.938 & -6.180 & 7.451 & 11.879 \\
X1 & 19.000 & 35.000 & -1.229 & -3.917 & 1.926 & 3.071 \\
Y & 22.000 & 55.000 & -2.181 & -6.954 & 8.291 & 13.217 \\
Multivariate & & & & & 25.826 & 12.055 \\
\hline
\end{tabular}

Based on the AMOS output for the above normality test, the value of c.r. (critical ratio) on the multivariate line is 12,055 . The value of c.r. which is between \pm 1.96 means the data is normally distributed[15].

Given the critical ratio value is outside the range \pm 1.96 . This means that assumptions are not met by normality. Since the normality test is not met, in AMOS, the SEM Bayes approach (nonparametric) is used, as an alternative to SEM Maximum Likelihood (parametric), which gives accurate results, when the assumption of normality is not met[14].

\section{3) Multicollinearity Test}

Multicollinearity test is a test to test whether there is a strong correlation between variables utilization of information technology, human resource capacity, reconciliation and internal control system.
Table 4.3 Multicollinearity test with AMOS

Correlations: (Group number 1 - Default model)

\begin{tabular}{|l|r|r|}
\hline & Estimate \\
\hline $\mathrm{X} 3<-->$ & $\mathrm{X} 4$ & .509 \\
$\mathrm{X} 2<-->$ & $\mathrm{X} 4$ & .392 \\
$\mathrm{X} 1<->>$ & $\mathrm{X} 3$ & .259 \\
$\mathrm{X} 1<-->$ & $\mathrm{X} 2$ & .459 \\
$\mathrm{X} 1<-->$ & $\mathrm{X} 4$ & .569 \\
$\mathrm{X} 2<-->$ & $\mathrm{X} 3$ & .386
\end{tabular}

It is known that all correlation values (Estimate columns) are below 0.9. The correlation value less than 0.9 indicated no multicollinearity symptoms[16].

\section{B. SEM with Bayes Method Estimation on AMOS Software}

Bayesian statistics use an iteration of the amount of resampling of very large data to achieve a normal distribution using the Markov Chain Monte Carlo (MCMC) method. The AMOS program has integrated MCMC into the program, so we can use the Bayesian estimation method.

An alternative approach with a Bayesian statistical model that considers that any unknown quantity is unknown as a random variable and given its probability distribution. So Bayesian introduces a method in which we need to know the shape of the prior distribution of the population by the bayes method. The population parameter is derived from a distribution so that the value is not single (a random variable), whereas according to the classical method (maximum likelihood) the population parameter is assumed to remain constant although its value is unknown[14].

\section{Testing Effect of Information Technology Utilization,}

Human Resource Capacity, Reconciliation, Internal Control System to Quality of Financial Statement

In the AMOS test with Bayes method it is known that the coefficient value of the line (Mean) in table 4.4 of the information technology utilization is 0.388 , the human resource capacity is 0.064 , the reconciliation is 0.367 , the internal control system is 0.209 . This means that the use of 
n...enc..men. technology, human resource capacity, reconciliation and internal control system have a positive effect on the quality of financial statements.

To know the positive influence is significant or not, then note the value of credible interval between lower bound and upper bound. Lower bound and upper bound of information technology utilization $0.266-0.512$, from human resource capacity $-0.034-0.164$, reconciliation $0.252-0.484$ and internal control system $0138-0.277$. If in the range of the lower bound and upper bound interval contains the number 0 , then the influence is not statistically significant[14]. From the results of SEM AMOS with Bayes approach, the influence of human resource capacity on the quality of financial report is not significant, while the utilization of information technology, human resource capacity, reconciliation, and internal control system have statistically significant effect.

Table 4.4 AMOS Results with Bayes Method (Nonparametric)

\begin{tabular}{|c|c|c|c|c|c|c|c|}
\hline & Mean & S.E. & S.D. & C.S. & $\begin{array}{c}50 \% \\
\text { Lower } \\
\text { Bound }\end{array}$ & $\begin{array}{c}50 \% \\
\text { Upper } \\
\text { Bound }\end{array}$ & Name \\
\hline Regression Weights & & & & & & & \\
\hline Y $\mathrm{X} 1$ & 0.388 & 0.005 & 0.189 & 1.000 & 0.266 & 0.512 & \\
\hline $\mathrm{Y} \leftarrow \mathrm{X} 2$ & 0.064 & 0.005 & 0.148 & 1.001 & -0.034 & 0.164 & \\
\hline $\mathrm{Y} \leftarrow \mathrm{X} 3$ & 0.367 & 0.005 & 0.176 & 1.000 & 0.252 & 0.484 & \\
\hline $\mathrm{Y} \leftarrow \mathrm{X} 4$ & 0.209 & 0.004 & 0.105 & 1.001 & 0.138 & 0.277 & \\
\hline
\end{tabular}

The value of Squared Multiple Correlations is 0.465 . This means that the influence of the use of information technology, human resource capacity, reconciliation, and internal control system on the quality of financial statements of 0.465 or $46.5 \%$, the remaining $53.5 \%$ influenced by other factors.

Table 4.5 Coefficient of Determination

Squared Multiple Correlations: (Group number 1 - Default model)

\begin{tabular}{|l|r|}
\hline & Estimate \\
\hline $\mathrm{Y}$ & .465 \\
\hline
\end{tabular}

\section{Moderating Test Results}

In this study used residual test. Here are the results of PPK SKPD role testing in moderating the relationship between the utilization of information technology, human resource capacity, reconciliation, internal control system to the quality of financial statements with residual test approach.

Table 4.6 Moderating Test Results

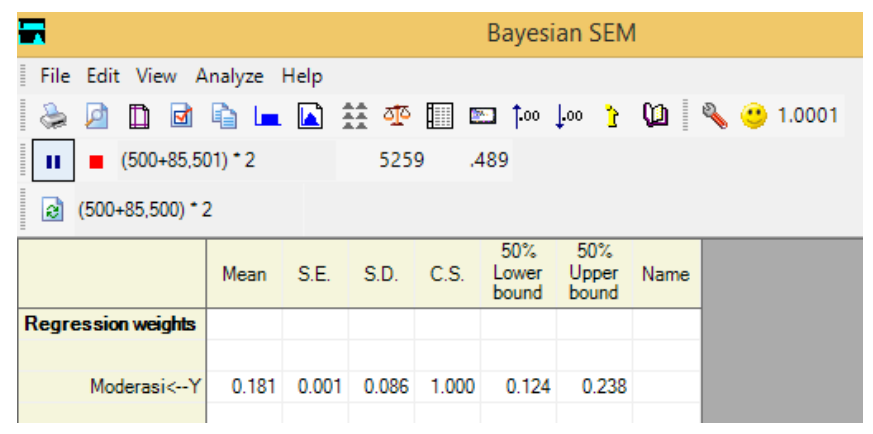

Significant determination or not in SEM Bayes approach used credible valueinterval if in the range of the lower bound and upper bound interval contains the number 0 , then the influence is not statistically significant.

Based on Figure 3.6, it is known that the credible interval lower bound 0.124 and the upper bound is 0.238 , which does not contain the number 0 . This means that the role of PPK
SKPD has a significant influence in moderating the relationship between information technology utilization, human resource capacity, reconciliation, internal control system on quality financial statements.

\section{CONCLUSIONS AND SUGGESTIONS}

\section{A. Conclusion}

Based on the discussion of research results it can be taken some conclusions:

1. The results of data analysis show that human resource capacity is not significant to the quality of financial statements. This means responsibility, education, training and experience have no effect on the quality of financial statements. While the utilization of information technology, reconciliation and internal control system significantly influence the quality of financial statements.

2. The role of PPK SKPD can moderate the relationship between the use of information technology, human resource capacity, reconciliation, and internal control system on the quality of financial statements.

\section{B. Limitations}

1. The research object is limited to Deli Serdang Regency and Research Respondent is only financial sub-treasury, treasurer of receipt, expense treasurer and operator.

2. Distribution of questionnaires on some SKPD still have problems in filling questionnaires such as lack of caring attitude and seriousness in answering the questions given so as to cause the data processed less than optimal.

3. Research data from respondents submitted in writing in the form of questionnaires will affect the results of research because the perceptions of respondents who delivered not necessarily reflect the actual situation (subjective) and will be different if the data obtained through direct interviews with respondents.

\section{Suggestion}

Based on the above conclusions, the suggestions that can be put forward in this research are:

1. The object of research for subsequent research should be extended to other districts and respondents in subsequent research are not limited to financial sub-treasury, treasurer of receipt, expense treasurer and operator but may also be added the power of budget users or budget users as respondents. 
.. .... financial sub-treasurers and treasurers in each SKPD have different disciplinary backgrounds (not only from the background of accounting knowledge). Thus if an employee who is not from the discipline of accounting is placed as a financial sub-treasury and treasurer of SKPD should be given sufficient briefing on the basics of accounting.

3. Adding other variables that are expected to affect the quality of financial statements considering the research variables used today can only explain by $46.5 \%$.

\section{Acknowledgment}

The author gratefully acknowledges that the research presented is supported by the University of North Sumatra (USU) to complete the author's final project.

\section{References}

[1] Partono. 2000. Laporan Keuangan Pemerintah: Upaya Menuju Transparansi dan Akuntabilitas. Media Akuntansi.PT. Reflika Aditama.

[2] Peraturan Pemerintah Nomor 71 Tahun 2010 tentang Standar Akuntansi Pemerintah.

[3] www.deliserdangkab.go.id, accessed on 13 August 2016

[4] www.bpk.go.id, accessed on 13 August 2016

[5] Peraturan Pemerintah Nomor 65 Tahun 2010 tentang Sistem Informasi Keuangan Daerah.

[6] www.bpkp.go.id, accessed on August 2016

[7] Mardiasmo. 2002. Akuntansi Sektor Publik. Yogyakarta: Andi.

[8] Mardiasmo. 2004. Akuntansi Sektor Publik. Yogyakarta: Andi.

[9] Boynton, William C. Johnson., Raymond N. and Kell, Walter G. 2001. Modern Auditing. Edisi ke-7. Erlangga, Jakarta.

[10] Pradono, Febrian Cahyo dan Basukianto. 2015. Kualitas Laporan Keuangan Pemerintah Daerah: Faktor yang Mempengaruhi dan Implikasi Kebijakan (Studi pada SKPD Pemerintah Provinsi Jawa Tengah).Jurnal Bisnis dan Ekonomi (JBE). Hal. 188 - 200. Vol. 22, No. 2

[11] Zuliarti. 2012. Pengaruh Kapasitas Sumber Daya Manusia, Pemanfaatan Teknologi Informasi dan Pengendalian Inntern Akuntansi Terhadap Nilai Informasi Pelaporan Keuangan Pemerintah Daerah: Studi pada Pemerintah Kabupaten Kudus. Skripsi. Tidak Dipublikasikan.

[12] Peraturan Pemerintah Nomor 60 Tahun 2008 tentang Sistem Pengendalian Intern Pemerintah.

[13] Wilkinson, Josep W. Et al. 2000. Accounting Information System Essential Concept and Application. 4 Edition, Jhon Willey \& Sons Inc, New York-USA.

[14] Ghozali, Imam. 2014. Model Persamaan Struktural Konsep dan Aplikasi dengan Program AMOS 22.0. Semarang: Universitas Diponegoro.

[15] Agus, Widarjono. 2015. Analisis Multivariat Terapan Yogayakarta: Penerbit UPP STIM YKPN.

[16] Ghozali, Imam. 2013. Aplikasi Analisis Multivariate dengan Program SPSS. Semarang: Universitas Diponegoro. 